\title{
Sensitivity of polymerase chain reaction for detection of known aliquots of Trypanosoma cruzi in the blood of mice: an in vitro study
}

\author{
Sensibilidade da reação em cadeia da polimerase para a detecção \\ de alíquotas conhecidas do Trypanosoma cruzi ino sangue \\ da camundongos: estudo invitro.
}

Rozália F. Campos ${ }^{1,3}$, Juracy B. Magalhães', Eliana A.G. Reis ${ }^{2}$, Mitermayer G. Reis ${ }^{2}$ and Sonia G. Andrade ${ }^{1}$

\begin{abstract}
To evaluate the sensitivity of polymerase chain reaction $(P C R)$ to reveal known number of trypomastigote in the blood of mice, three separate experiments were done. First: To eight samples of 500ul of normal mice blood, one aliquot of 1, 2, 3, 4, 5, 10, and 50 trypomastigotes respectively, were added. Second and third: 10 aliquots with 1 and 10 with 2 trypomastigotes were added to samples of 500 $\mu$ lof normal mice blood. Positive control: 500 $\mu$ l of blood containing 100,000 trypomastigotes. For kDNA minicircles amplification by PCR the primers:S35 and S36 were used. PCR revealed products of 330 b.p in the positive controls. When only one sample with the aliquots of 1 or 2 trypomastigotes was examined, results were negative; results were positive with aliquots of 3 to 50 trypomastigotes. In the $2^{\text {nd }}$ and $3^{\text {rd }}$ experiments, $9 / 10$ aliquots with one parasite and 9/10 with 2 trypomastigotes were positive revealing a high sensitivity of this reaction. In conclusion, the presence of one single parasite in $500 \mu \mathrm{l}$ of blood, is enough for a positive PCR. This method could be used as a complement to the various parasitological cure tests in treated mice, when low volumes of blood are individually examined.
\end{abstract}

Key-words: Trypanosoma cruzi. Polymerase chain reaction. PCR sensitivity in mice. PCR as cure test in mice.

Resumo A sensibilidade da reação em cadeia da polimerase (PCR) para revelar a presença de números conhecidos de tripomastigotas no sangue de camundongos, foi investigada em três experimentos separados. No primeiro, foram adicionados 1, 2, 3, 4, 5, 10, 20 e 50 tripomastigotas respectivamente, em oito amostras de $500 \mu /$ de sangue de camundongo. No $2^{\circ}$ e $3^{\circ}$ experimentos: foram feitas 10 amostras contendo 1 , e 10 amostras contendo 2 tripomastigotas $/ 500 \mu l$ de sangue. Controle positivo: $500 \mu l$ de sangue contendo 100.000 trypomastigotas. Para amplificação dos minicirculos do kDNA pela PCR foram usados os iniciadores S35e S36. A PCR revelou produtos de 330 p.b nos controles positivos e nas amostras contendo de 3 a 50 tripomastigotas. Quando apenas uma amostra contendo 1 ou 2 tripomastigotas foi examinada, os resultados foram negativos, porém no $2^{\circ}$ e $3^{\circ}$ experimentos 9/10 amostras contendo 1 e 2 tripomastigotas foram PCR positivas, revelando alta sensibilidade da reação. Em conclusão, a presença de um só parasito em $500 \mu l$ de sangue é suficiente para uma PCR positiva e este método pode ser usado como complementação dos demais testes parasitológicos de cura, em camundongos tratados, quando pequenos volumes de sangue são individualmente examinados.

Palavras-chaves: Trypanosoma cruzi. Reação em cadeia da polimerase. Sensibilidade da PCR em camundongos. PCR como teste de cura.

\footnotetext{
1. Laboratório de Doença de Chagas Experimental do Centro de Pesquisas Gonçalo Moniz da Fundação Instituto Oswaldo Cruz. Salvador, BA. 2. Laboratório de Patologia e Biologia Molecular do Centro de Pesquisas Gonçalo Moniz da Fundação Instituto Oswaldo Cruz, Salvador, BA; 3. Departamento de Ciências Biológicas da Universidade Estadual de Feira de Santana, Feira de Santana, BA.

Financial support: PAPES 2 -FIOCRUZ-Rio de Janeiro

Address to: Dra. Sonia Gumes Andrade. Centro de Pesquisas Gonçalo Moniz. Valdemar Falcão 121, Brotas, 40295-001 Salvador, BA, Brasil.

Tel: 71 356-4292-R212, Fax: 71 356-4292/4667

e-mail :sgandrade@cpqgm.fiocruz.br

Recebido para publicação em 26/11/2001
} 
Polymerase chain reaction (PCR), has been used as a method for detection of Trypanosoma cruzi infection in individuals with chronic Chagas' disease ${ }^{2}{ }^{9}$ and as a parasitological cure-test for Chagas' disease in treated patients ${ }^{6} 18$ showing higher sensitivity when compared to parasitological and serological tests ${ }^{45}{ }^{18}$. The sensitivity of PCR to detect the presence of fragments of T. cruzi DNA has been investigated by several authors that used different methods, either to amplify the fragments of $\mathrm{kDNA}^{3}{ }^{16}$, of the satellite DNA ${ }^{10}$ or the nuclear DNA ${ }^{12131415}$ or of the ribosomal $\mathrm{RNA}^{17}$. Several primers have been used for the identification of fragments with different base pairs. Experimentally, Vargas et $\mathrm{al}^{18}$, testing different dilutions of blood of infected mice determined the positivity of PCR by the identification of fragments of 270 b.p until a dilution of $1 \times 10^{-2}$ parasites $/ \mathrm{ml}$. However these data did not establish the exact number of parasites in each sample nor clarified the number of samples to examine in order to obtain such results.

Investigations of the sensitivity of PCR to reveal the minimal quantities of the T. cruzi kDNA when applied to small volumes of blood individually obtained from mice was performed. For that investigation, a precise number of trypomastigotes was added to $500 \mu$ l of normal mouse blood, representing known aliquots of parasites. The presence of fragments of 330 base pairs (b.p) of the variable region of the minicircles of kDNA in these samples, were investigated by the PCR technique.

Investigation of the sensitivity of PCR to reveal parasites in the blood of mice with a sub patent parasitemia is important, because this reaction can be used as a cure test in the evaluation of experimental chemotherapy of T. cruzi infection. Several conventional parasitological tests, when combined, can disclose sub patent infections in mice submitted to treatment but not cured ${ }^{1}$. PCR can also be used as a complementary cure test in mice individually examined for cure confirmation. The accuracy of cure tests is important for monitoring the efficacy of new drugs or the resistance of different strains of $T$. cruzi to treatment. However, some peculiarities of the experiments performed in animals, require a validation for the tests usually applied in humans. In the case of PCR, one of the obstacles is the small volume of blood available from each mouse, when individual examination becomes necessary. Since the cure rates are established by the percentage of cured mice, the demonstration of negativity has to be done for each treated animal.

In the present investigation, we intend to contribute to the establishment of the sensitivity of PCR to reveal a low known number of parasites and to define the minimum number that could be identified through PCR, using progressive aliquots obtained by micromanipulation from the peripheral blood of mice.

\section{MATERIAL AND METHODS}

Trypanosoma cruzi aliquots. Trypomastigote forms of $T$. cruzi were isolated from the peripheral blood of mice experimentally infected with 21 SF strain using a micromanipulation technique by isolating one single parasite from peripheral mouse blood as described previously $^{8}{ }^{11}$. The aliquots containing from 1 to 50 trypomastigotes were obtained by adding the precise number of parasites to $500 \mu$ of normal mouse blood.

Methodology. Three experiments were developed as follows:

$1^{\text {st }}$ experiment: in the $1^{\text {st }}$ experiment, to eight samples of $500 \mu \mathrm{l}$ of normal mice blood, aliquots of $1,2,3,4,5$, 10, 20 and 50 trypomastigotes were added, respectively.

$2^{\text {nd }}$ and $3^{\text {rd }}$ experiments: five aliquots with 1 trypomastigote and 5 with 2 trypomastigotes, added to $500 \mu \mathrm{l}$ of normal mice blood, were analyzed in each experiment, performing a total of 10 samples containing one parasite and 10 containing two parasites. The DNA extraction was performed separately for each experiment.
Positive control: a sample of peripheral blood obtained from one infected mouse, containing $1 \times 10^{5}$ trypomastigotes in $500 \mu$ l was used.

Polymerase chain reaction. The kDNA extraction was performed with DNAzol $(1 \mathrm{ml}$ of the reagent to $100 \mu \mathrm{l}$ of blood), precipitation of the DNA with ethylic alcohol and solubilization with ultrapure water. Amplification in $50 \mu \mathrm{l}$ of the reaction mixture containing $10 \mathrm{mM}$ Tris $/ \mathrm{HCl}$ (pH 8.4), $50 \mathrm{mM} \mathrm{KCl,} 2.0 \mathrm{mM} \mathrm{MgCl} 200 \mu \mathrm{M}$ of each dNTP, $2,5 \mathrm{U}$ of Taq polymerase (Perkin-ËImer-Cetus) 2 pmols of oligonucleotide primers, $4 \mu \mathrm{LNA}$. The oligonucleotide primers used for PCR were: S35, and S36, according to Avila et $\mathrm{al}^{3}$, hybridize for the constant region of the kDNA and produces PCR products of $330 \mathrm{bp}^{16}$. After an initial four-minute denaturation at $94^{\circ} \mathrm{C}, 35$ cycles of amplification were performed on DNA Thermal Cycler (Perkin Elmer-Cetus, with a step program consisting of $94^{\circ} \mathrm{C} 45 \mathrm{sec}, 55^{\circ} \mathrm{C} 45 \mathrm{sec}, 72^{\circ} \mathrm{C} 1 \mathrm{~min}, 72^{\circ} \mathrm{C} 10 \mathrm{~min}$. PCR products $(330 \mathrm{bp})$ were separated by electrophoresis in a $2 \%$ agarose gel and stained with ethidium bromide.

\section{RESULTS}

The polymerase chain reaction, was evaluated by the presence of bands of 330 base pair at the electrophoretic analysis of the amplified fragments of the variable portion of the minicircles of the kinetoplast DNA.

The positive control reveals the amplification of the $330 \mathrm{bp}$ fragments.

In the $1^{\text {st }}$ experiment, PCR resulted negative when only one sample containing 1 or 2 trypomastigotes was examined, but the samples containing 3, 5, 10, 20, or 30 forms were positive (Figure $1 \mathrm{~A}$ ).

In the $2^{\text {nd }}$ and $3^{\text {rd }}$ experiments, from 10 samples containing the aliquots of 1 trypomastigote, 9 were Positive (90\%) and from 10 samples with the aliquot of 2 trypomastigotes, 9 were Positive (90\%). Results of the $2^{\text {nd }}$ experiment are shown in Figure $1 \mathrm{~B}$. 


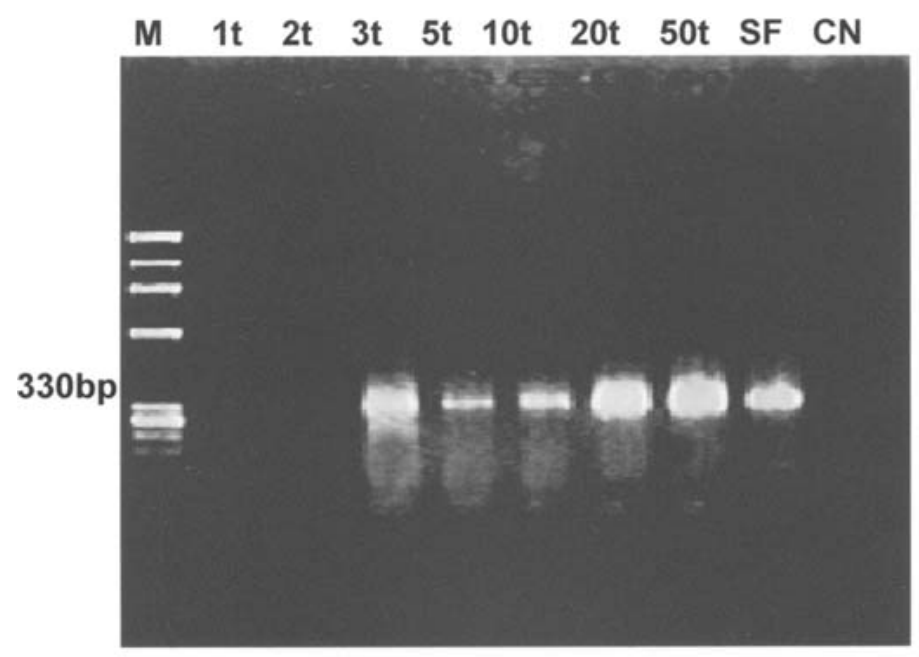

A

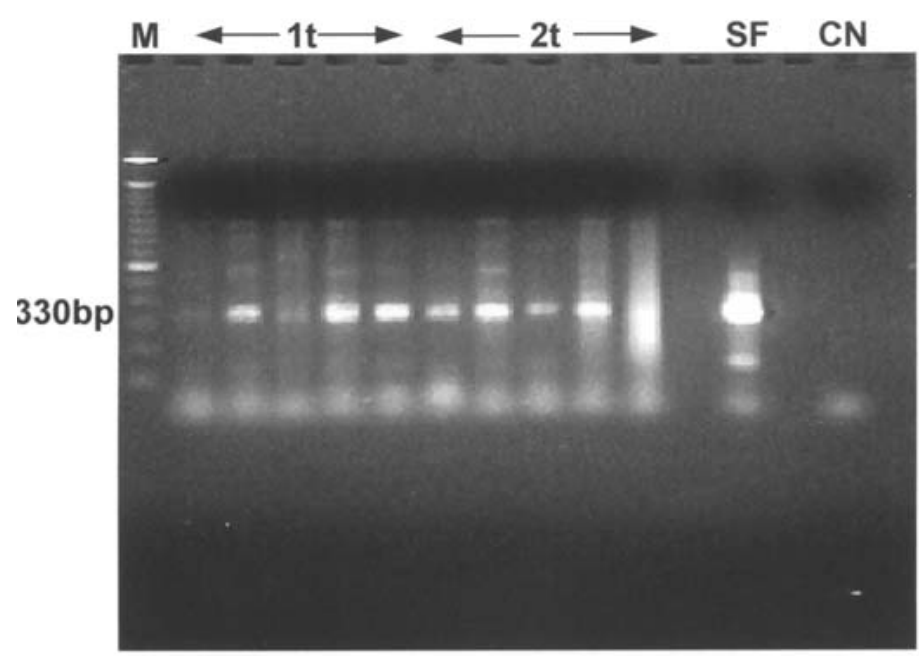

B

Figure 1 - $\boldsymbol{A})$ First Experiment - $P C R$ of samples containing 1 to 50 trypomastigotes $(t): M$ - marker; $S F$ - strain; $C N$ - negative control. Negative for 1 and 2 trypomastigotes and positive for 3-50 trypomastigotes. B) Second experiment - PCR of five samples containing 1 trypomastigote (t) and 5 samples containing 2 trypomastigotes. Four of five (4/5) samples containing 1 parasite were positive including one that revealed a weak band; all samples with two parasites were PCR positive.

\section{DISCUSSION}

The possibility of confirming the presence of parasites in the blood of chronically infected mice, has been the objective of various authors. Diaz et al ${ }^{10}$ used PCR of T. cruzi satellite DNA from nuclei, instead of whole blood, to enhance sensitivity in the detection of the parasite in blood and tissues of chronically infected mice. Although most mice were parasite-positive when organs or tissues were tested, all were negative when total blood was submitted to this method. Silber et al ${ }^{14}$, using the primers BP1/BP2 for detect the nuclear DNA of $T$. cruzi demonstrated that the minimum quantity of DNA necessary for amplification was $1 \mathrm{pg}$ that, indirectly, by calculations, corresponded to 0.5 parasite $/ \mathrm{ml}$. These results were obtained by using a minimum of 5 parasites for $1 \mathrm{ml}$. Inasmuch a cross reaction with $T$. rangeli was present. As previously referred, Vargas et $\mathrm{al}^{18}$, through different dilutions has done an indirect evaluation of the sensitivity of PCR in mice. 
The present investigation has demonstrated that a unique trypomastigote blood form, obtained by micromanipulation and added to normal blood, can be detected by the PCR in $500 \mu \mathrm{l}$ of blood. This represents an important contribution for the evaluation of cure post chemotherapy in mice. However, there were cases in which parasites in low number were not revealed, probably due to DNA loss during the process of extraction. In those cases, repeated tests must be performed in order to obtain a final diagnosis as was shown in the present investigation, in which the PCR positivation in aliquots of 1 or 2 parasites did not occur with a single sample examination.
In a previous study ${ }^{7}$, using mice submitted to specific chemotherapy, in which PCR has been used as a cure test, correlation between positivity of parasitological tests with positive PCR was of $37 \%$ only. In consequence, negative PCR can be the result in mice presenting other positive parasitological tests.

Demonstration of the sensitivity of PCR to reveal a small number of parasites, confirms previous reports in the literature. However analysis of the present results indicates that PCR should not be used in substitution of the various parasitological tests, but as a complementary test when low volumes of blood are individually examined.

\section{REFERENCES}

1. Andrade SG, Magalhães JB, Pontes AL. Evaluation of chemotherapy with Benznidazole and Nifurtimox in mice infected with Trypanosoma cruzi strains of different types. Bulletin of the World Health Organization 63: 721-726, 1985.

2. Avila HA, Pereira JB, Thiemann O, de Paiva E, Degrave W, Morel, CM, Simpson L. Detection of Trypanosoma cruzi in blood specimens of chronic chagasic patients by polymerase chain reaction amplification of kinetoplast minicircle DNA: Comparison with serology and xenodiagnosis. Journal of Clinical Microbiology 31: 2421-2426, 1993

3. Avila HA, Sigman DS, Cohen LM, Millikan RC, Simpson L. Polymerase chain reaction amplification of Trypanosoma cruzi kinetoplast minicircle DNA isolated from whole blood lysates: diagnosis of chronic Chagas' disease. Molecular and Biochemical Parasitology 48: 211-222, 1991

4. Britto C, Cardoso MA, Ravel C, Santoro A, Pereira JB, Coura JR, Morel CM, Wincker P. Trypanosoma cruzi: Parasite detection and strain discrimination in chronic chagasic patients from northeastern Brazil using amplification of kinetoplast DNA and nonradioactive hybridization. Experimental Parasitology 81: 462-471, 1995.

5. Britto C, Cardoso MA, Vanni CMM, Hasslocher-Moreno A, Xavier S, Oeleman W, Santoro A, Pirmez C, Morel CM, Wincker P. Polymerase chain reaction detection of Trypanosoma cruzi in human blood samples as a tool for diagnosis and treatment evolution. Parasitology 110: 241-247, 1995.

6. Britto C, Macedo V, Silveira C, Cardoso A, Marques P, Fernandes O. Potencial de aplicação da técnica de PCR na determinação de cura parasitológica em pacientes chagásicos crônicos submetidos a quimioterapia específica. Revista da Sociedade Brasileira de Medicina Tropical 32 (supl II): 77-78, 1999.

7. Camandaroba ELP, Reis EG, Gonçalves MS, Reis MG, Andrade SG. Suscetibilidade de clones isolados da cepa Colombiana do Trypanosoma cruzi ao tratamento com Benzonidazol. Avaliação da reacção da cadeia da polimerase (PCR) como teste de cura. Revista da Sociedade Brasileira de Medicina Tropical 34 (supl I): 145, 2001.

8. Campos RMF, Andrade SG. Characterization of subpopulations (clones and subclones) of the 21SF strain of Trypanosoma cruzi after long lasting maintenance in the laboratory. Memórias do Instituto Oswaldo Cruz 91: 795-800, 1996.
9. Chiari E. Chagas disease diagnosis using polymerase chain reaction, hemoculture and serologic methods. Memórias do Instituto Oswaldo Cruz 94 (supl I): 299-300, 1999.

10. Diaz C, Nussenzweig V, Gonzalez A. An improved polymerase chain reaction assay to detect Trypanosoma cruzi in blood. American Journal of Tropical Medicine and Hygiene 46:616-623, 1992.

11. Dvorak, JA. Single cell isolates of Trypanosoma cruzi: How and Why? Revista da Sociedade Brasileira de MedicinaTropical 18:29-38, 1985

12. Moser DR, Kirchoff LV, Donelson JE. Detection of Trypanosoma cruzi by DNA amplification using the polymerase chain reaction. Journal of Clinical Microbiology 27: 1477-1482, 1989.

13. Requena JM, Jimenez-Ruiz A, Soto M, Lopez MC, Alonso C. Characterization of a highly repeated interspersed DNA sequence of Trypanosoma cruzi: its potential use in diagnosis and strain classification. Molecular and Biochemical Parasitology 51: 271-280, 1992.

14. Silber AM, Búa J, Porcel BM,Segura, EL, Ruiz AM. Trypanosoma cruzi: Specific detection of parasites by PCR in infected humans and vectors using a set of primers (BP1/BP2) targeted to a nuclear DNA sequence. Experimental Parasitology 85: 225-232, 1996.

15. Souto RP, Zingales B. Sensitive detection and strain classification of Trypanosoma cruzi by amplification of ribosomal RNA sequence. Molecular and Biochemical Parasitology 62: 45-52, 1993.

16. Sturm NR, Degrave W, More C, Simpson L. Sensitive detection and schizodeme classification of Trypanosoma cruzi by amplification of kinetoplast minicircle DNA sequences: use in diagnosis of Chagas disease. Molecular and Biochemical Parasitology 33: 205-214, 1989.

17. Vargas, D, Wallace A, Solari A. Estandarizacion de la reaccion de la polimerizacion en cadena (PCR) en muestras de sangue de ratones infectados con Trypanosoma cruzi. Parasitologia Al Dia 20: 136-140, 1996.

18. Wincker P, Britto C, Pereira JB, Cardoso MA, Oelemann W, Morel $\mathrm{CM}$. Use of a simplified polymerase chain reaction procedure to detect Trypanosoma cruzi in blood samples from chronic chagasic patients in a rural endemic area. American Journal of Tropical Medicine and Hygiene 51:771-777, 1994. 